\title{
The effect of rumen isolated bacteria on degradation of sugarcane pith processed with steam and or exogenous enzyme in in vitro culture condition
}

T Mohammadabadi, M Chaji

Department of Animal Science, Ramin Agriculture and Natural Resource University, Molasani, Ahvaz, Islamic Republic of Iran

Email:mohammadabadi@gmail.com

Introduction Rumen cellulolytic bacteria, such as Ruminococcus albus have a key role in ruminal digestion of plant cell walls, due to their numerical predominance and metabolic diversity (Cheng et al., 1991). Many methods have proved successful in disrupting cell wall material e.g. using enzyme (Eun and Beauchemin, 2007), and or steam (Castro and Machado, 1990). Steam explosion resulted in to disrupt lignocellulosics and partial or complete hydrolysis of hemicellulose fraction in a way which allows improved utilization of cell wall polysaccharides by rumen microbes and improving enzymatic accessibility and digestibility (Castro and Machado, 1990). Researchers reported increasing of in vitro DM digestibility for sugarcane pith treated with steam by about 14\% (Chaji and Naserian, 2006). The objective of this experiment was to estimate the in vitro disappearance of dry matter (DM) and neutral detergent fiber (NDF) of untreated sugarcane pith and treated with steam and or enzyme $(4 \mathrm{~g} / \mathrm{kg} \mathrm{DM})$ by rumen isolated bacteria.

Material and methods Four fistulated sheep was used to collect rumen fluid which fed $250 \mathrm{~g}$ concentrate, $550 \mathrm{~g}$ lucerne hay and $200 \mathrm{~g}$ wheat straw, then centrifuged (1000 rpm, $10 \mathrm{~min})$. Supernatant was used to grow bacteria in medium containing fungicides (benomyle: $500 \mathrm{ppm} / \mathrm{ml}$ medium and metalaxyle: $10 \mathrm{mg} / \mathrm{ml}$ medium) under anaerobic conditions at $39{ }^{\circ} \mathrm{C}$ for $24 \mathrm{~h}$. These isolates were then used as a source of inoculum for culturing bacteria in a serum bottle containing 45 $\mathrm{ml}$ of culture medium of rumen bacteria (Galdwell and Bryant, 1966) and 1g of sugarcane pith as untreated (USP), treated with steam (SSP, at 19 bar for $3 \mathrm{~min} 70 \%$ moisture) and or with exogenous enzyme (ESP, $4 \mathrm{~g} / \mathrm{kg}$ DM, the enzyme mixture composition was Cellulase, Xylanase, Betaglucanase, Alpha amylase, Pectinase, Phytase, Protease and Lipase as 0.03, 6.6, 10, 0.7, 0.7, 0.07, 0.5 and $3 \mathrm{MU} / \mathrm{kg}$, respectively; Bioproton Pty. Ltd. Co.) under anaerobic conditions (using three times subculture), at $39{ }^{\circ} \mathrm{C}$ for $12,24,48,72$ and $96 \mathrm{~h}$ ( 3 replicates per time). The residual substrates of each bottle were then filtered and used to determine the DM and NDF concentrations. Data of DM and NDF disappearance in different times were analyzed as a completely randomized design using the General Linear Model (GLM) procedure of SAS (1990). Duncan's multiple range test was used to compare the means at $\mathrm{P}<0.05$.

Results Disappearance of DM and NDF of samples using rumen isolated bacteria culture are given in Table 1. Sugarcane pith treated with steam had the highest disappearance rate of DM and NDF of in each incubation time $(\mathrm{P}<0.05)$ in compared with the other samples, using in vitro bacterial culture.

Table 1 Disappearance of DM and neutral detergent fibre of sugarcane pith treated with steam and or enzyme by rumen bacteria

\begin{tabular}{lllllllllll}
\hline $\begin{array}{l}\text { Incubation } \\
\text { time }(\mathrm{h})\end{array}$ & \multicolumn{4}{c}{ DM disappearance $(\mathrm{g} / 100 \mathrm{~g})$} & \multicolumn{4}{c}{ NDF disappearance $(\mathrm{mg} / \mathrm{g})$} \\
& USP & SSP & ESP & s.e.d & P & USP & SSP & ESP & s.e.d & P \\
\hline 12 & $34.2^{\mathrm{c}}$ & $45.0^{\mathrm{a}}$ & $39.3^{\mathrm{b}}$ & 0.65 & $<.0001$ & $87.2^{\mathrm{c}}$ & $148.0^{\mathrm{a}}$ & $105.3^{\mathrm{b}}$ & 0.62 & $<.0001$ \\
24 & $36.4^{\mathrm{c}}$ & $51.1^{\mathrm{a}}$ & $45.6^{\mathrm{b}}$ & 0.51 & $<.0001$ & $164.4^{\mathrm{c}}$ & $217.1^{\mathrm{a}}$ & $199.6^{\mathrm{b}}$ & 0.71 & $<.0001$ \\
48 & $47.2^{\mathrm{c}}$ & $63.2^{\mathrm{a}}$ & $55.1^{\mathrm{b}}$ & 0.72 & $<.0001$ & $236.2^{\mathrm{c}}$ & $302.2^{\mathrm{a}}$ & $271.1^{\mathrm{b}}$ & 0.80 & $<.0001$ \\
72 & $56.1^{\mathrm{c}}$ & $71.1^{\mathrm{a}}$ & $60.2^{\mathrm{b}}$ & 0.70 & $<.0001$ & $244.1^{\mathrm{c}}$ & $314.1^{\mathrm{a}}$ & $285.2^{\mathrm{b}}$ & 0.75 & $<.0001$ \\
96 & $58.3^{\mathrm{c}}$ & $73.3^{\mathrm{a}}$ & $63.3^{\mathrm{b}}$ & 0.42 & $<.0001$ & $247.3^{\mathrm{c}}$ & $317.3^{\mathrm{a}}$ & $287.3^{\mathrm{b}}$ & 0.62 & $<.0001$ \\
\hline \hline
\end{tabular}

Means with different letters within each row, differed significantly $(P<0.05)$

Conclusions The present experiment showed in vitro bacterial digestion of DM and NDF of sugarcane pith was increased by steam or enzyme, and the effect of steam was more than enzyme. Results of the present study confirmed results Nsereko et al. (2000) that reported enzyme products containing xylanases and esterases had stimulatory effects on fibre degradation of alfalfa hay. Also Toussaint et al. (1991) reported the increase in enzymic hydrolysis after steam treatment. Results of the present study indicated DM and NDF digestion of sugarcane pith by bacteria could be improved by steam and or exogenous enzyme.

\section{References}

Castro, F.B. and Machado, P.F. 1990. Livestock Research of Rural Development 2 (1).

Chaji, M. and Naserian, A.A. 2006. Proceeding of British Society of Animal Science, 182.

Cheng, K.J., Forsberg, C.W., Minato, H., and Costerton, J.W. 1991. In: Physiological Aspects of Digestion and Metabolism in Ruminants (Tsuda, T., Sasaki, Y. \& Kawashima, R., eds.), 595-624. Academic Press, Toronto, ON

Euna, J.-S., Beauchemin, K.A., Hongb, S.-H., and Bauer, M.W. 2006. Animal Feed Science and Technology 131, 86-101.

Galdwell, D.R. and Bryant, M.P. 1966. Applied Microbiology 14, 794-801.

Nsereko, V.L., Morgavi, D.P., Rode, L.M., Beauchemin, K.A. and McAllister, T.A. 2000. Animal Feed Science and Technology 88, 153-170.

Toussaint, B., Excofier, G., and Vignon, M.R. 1991. Animal Feed Science and Technology 32, 235-242. 